\title{
Effect of high pressure and soy protein isolate combinations on the water holding capacity and texture of pork meat batters
}

\author{
Valerii Sukmanov ${ }^{1}$, Ma Hanjun ${ }^{2}$, Yan-ping Li ${ }^{1,2}$ \\ 1 - Sumy National Agrarian University, Sumy, Ukraine \\ 2 - Henan Institute of Science and Technology, Xinxiang, PR China
}

Keywords:

Pressure

Soy

Protein

Water holding

capacity

Texture

Low-field NMR

Article history:

Received 12.11.2018

Received in revised

form 04.03.2019

Accepted 31.05.2019

Corresponding
author:

Ma Hanjun

E-mail:

xxhjma@126.com

DOI: $10.24263 / 2304-$

974X-2019-8-2-8

\section{Abstract}

Introduction. The used of high pressure and soy protein isolate combinations to emulsion meat products could improve the quality, water holding capacity, texture and increase product yield.

Materials and methods. Raw pork batters were prepared as follows: $400 \mathrm{~g}$ pork meat, $80 \mathrm{~g}$ pork back-fat, $70 \mathrm{~g}$ ice water, $10 \mathrm{~g}$ $\mathrm{NaCl}$; sample C2 had $10 \mathrm{~g}$ soy protein isolate $(2 \%)$; sample $\mathrm{C} 3-$ $20 \mathrm{~g}$ soy protein isolate $(4 \%)$. The vacuum packed batters were put into a high pressure vessel and were done with $200 \mathrm{MPa}$ for 10 min at $10 \pm 2^{\circ} \mathrm{C}$. The texture profile analysis of cooked pork batters were carried out using a texture analyzer. Low field NMR relaxation measurements were carried out according in the NMR probe of a Niumag Pulsed NMR analyzer.

Results and discussion. Compared with the $\mathrm{C} 1$, all the cooking yield of pork batters with various amount of soy protein isolate were increased significantly. The emulsifying activity of $11 \mathrm{~S}$ globulins was much significantly improved at $200 \mathrm{MPa}$, that enhanced the water holding capacity of soy protein isolate. High pressure processing induced texture modifications have been used to affect myofibrillar proteins and their gel-forming properties, raising the possibility of the development of processed comminuted meat products. Over $200 \mathrm{MPa}$ treatment, the protein extractability was decreased significantly in meat batters, and caused protein denaturation and/or aggregation, which limited their functionalities. The effects of relaxation time and peak ration of cooked pork batters by high pressure processing with different soy protein isolate were determined. There was three characteristic peaks in the cooked pork batters, which was named as $T_{2 b}, T_{21}$ and $T_{22}$, respectively. $T_{2 b}$ is assigned to water tightly associated to protein and macro-molecular constituents, the relaxation population centered at approximately $0-10 \mathrm{~ms}$ in the cooked pork batters. The relaxation population of $T_{21}$ is centered at approximately 10-100 ms, which is a major component and considered to intra-myofibrillar water and water within the protein structure.

Conclusion. The result of low field NMR exhibited that the batters with soy protein isolate had less water out the cooked pork batter and free water. Overall, the $2 \%$ soy protein isolate addition could improve the water holding capacity and texture of pork batters treated by high pressure. 


\section{- Food Technology -}

\section{Introduction}

The application of high pressure processing to modify the properties of meat and soy proteins, increase the water holding capacity and texture of cooked meat and soy proteins products. The used of high pressure and soy protein isolate combinations to emulsion meat products could improve the quality and lower the salt and fat content in the meat industry.

High pressure is a non-thermal technology that has been successfully applied to several meat products, and the applications of high pressure in food industry continue growing recently years [1,2]. The functions of high pressure in meat products contain the inactivation of microorganism and enzymes with minimal effects on flavor, color and nutritional quality [3-5]. Study [6] authors observed an increase in water holding capacity due to the interaction of high pressure processing and salt in pork meat batter, this may be because increasing sodium chloride causes increasing denaturation of muscle proteins in high pressure treated meat batters and favors the solubilization of proteins and the formation of a gel network that retains water and fat. Study [7] authors found that the textural properties of hardness, chewiness, springiness, cohesiveness and resilience were significantly $(\mathrm{P}<0.05)$ increased at an interval of $100 \mathrm{MPa}$ and $200 \mathrm{MPa}$, except the textural property of adhesiveness up to $200 \mathrm{MPa}$, but no changes of of hardness, chewiness, springiness and resilience were observed up to $300 \mathrm{MPa}$ and $400 \mathrm{MPa}$. Study [8] authors showed that free SH content of soy protein isolate was significantly $(\mathrm{P}<0.05)$ increased after high pressure treatment at $200 \mathrm{MPa}$. However, it is important to study the effect of high pressure processing on the food components, mainly proteins in the meat and soy to optimize the processing parameters to get high-quality products $[9,10]$. Soy protein isolate is a commonly useful vegetable protein in the meat industry, which has a good water and fat holding capacity, excellent gelling and structuring behaviour $[11,12]$. Some researchers have reported that added the soy protein isolate to meat batters could improve the water holding capacity, texture and nutritional quality. But few papers reported the effect of high pressure and soy protein isolate combinations on property of pork meat batter.

Therefore, the objective of the present study was to determine the water holding capacity and texture differences of pork meat batter which were produced by high pressure with soy protein isolate, and thereby to establish a method to obtain pork meat batter with desirable quality.

\section{Materials and methods}

\section{Raw materials and ingredients}

The longissimus dorsi of chilled pork (Moisture, $71.35 \pm 0.52 \%$; protein, $22.57 \pm 0.37 \%$; fat; $2.83 \pm 0.26 \% ; \mathrm{pH}, 5.63 \pm 0.02)$ were derived from the landrace $(100 \pm 5 \mathrm{~kg})$ which were slaughtered at the age of about 6 months provided by the Gaojin Group (China), and the temperature after slaughter $24 \mathrm{~h}$ was $2 \sim 4{ }^{\circ} \mathrm{C}$. After removing of the visible connective tissue and fat, the pork meat was minced using a meat chopper with a $6 \mathrm{~mm}$ holes plate (MGB-120, Shandong Jiaxin Food Machinery Co., Ltd., China). Pork back-fat $(90.21 \pm 0.56 \%$ fat) was purchased from a local meat market (Xinxiang, China), and also was minced using a meat chopper with a $6 \mathrm{~mm}$ holes plate. Soy protein isolate $(91.32 \pm 0.83 \%$ protein) was provided by Shandong Soy Foods co., Ltd (China). 


\section{Prepared pork batters}

Raw pork batters were prepared as follows: $\mathrm{C} 1,400 \mathrm{~g}$ pork meat, $80 \mathrm{~g}$ pork back-fat, $70 \mathrm{~g}$ ice water, $10 \mathrm{~g} \mathrm{NaCl}$; $\mathrm{C} 2,400 \mathrm{~g}$ pork meat, $80 \mathrm{~g}$ pork back-fat, $70 \mathrm{~g}$ ice water, $10 \mathrm{~g} \mathrm{NaCl}, 10 \mathrm{~g}$ soy protein isolate $(2 \%)$; $3,400 \mathrm{~g}$ pork meat, $80 \mathrm{~g}$ pork back-fat, $70 \mathrm{~g}$ ice water, $10 \mathrm{~g} \mathrm{NaCl}, 20 \mathrm{~g}$ soy protein isolate $(4 \%)$. The pork batters were produced by a bowl chopper (Stephan UMC5C, Germany). Briefly, the $400 \mathrm{~g}$ pork meat was placed into the bowl chopper with $20 \mathrm{~g}$ $\mathrm{NaCl}$. The mixture was chopped for $30 \mathrm{~s}$ with $1 / 3$ ice water, then the $80 \mathrm{~g}$ pork back-fat, $10 \mathrm{~g} / 20 \mathrm{~g}$ soy protein isolate $1 / 3$ ice water was added and the chopping was continued for $30 \mathrm{~s}$. Finally, the remaining ice water was added and chopped for $60 \mathrm{~s}$. During the chopping processing, the meat batters were maintained at a temperature below $8{ }^{\circ} \mathrm{C}$. The raw pork batters were then stuffed into $24 \mathrm{~mm}$ diameter polyamide casings (Xianyi casing Co., Ltd., Henan, China) using a sausage stuffer machine (Xiaojin Machinery Co., Ltd., Hebei Shijiazhuang, China) and linked every $160 \mathrm{~mm}$. Finally, the batters were vacuum packed for subsequent pressure processing.

\section{High pressure treatment}

High pressure treatments of sausage batters were carried out in a $0.3 \mathrm{~L}$ capacity high pressure vessel (S-FL-850-9-W/FPG5620YHL, Stansted Fluid Power Ltd., Stansted, UK) which has a maximum pressure limit of $900 \mathrm{MPa}$ and can work in the temperature range of $20^{\circ} \mathrm{C}$ to $+90^{\circ} \mathrm{C}$ with a thermo-stated jacket (Figure 1). Product canister: $260 \mathrm{~mm}$ internal usable height with demountable thermacouple, $37 \mathrm{~mm}$ internal usable diameter [13].

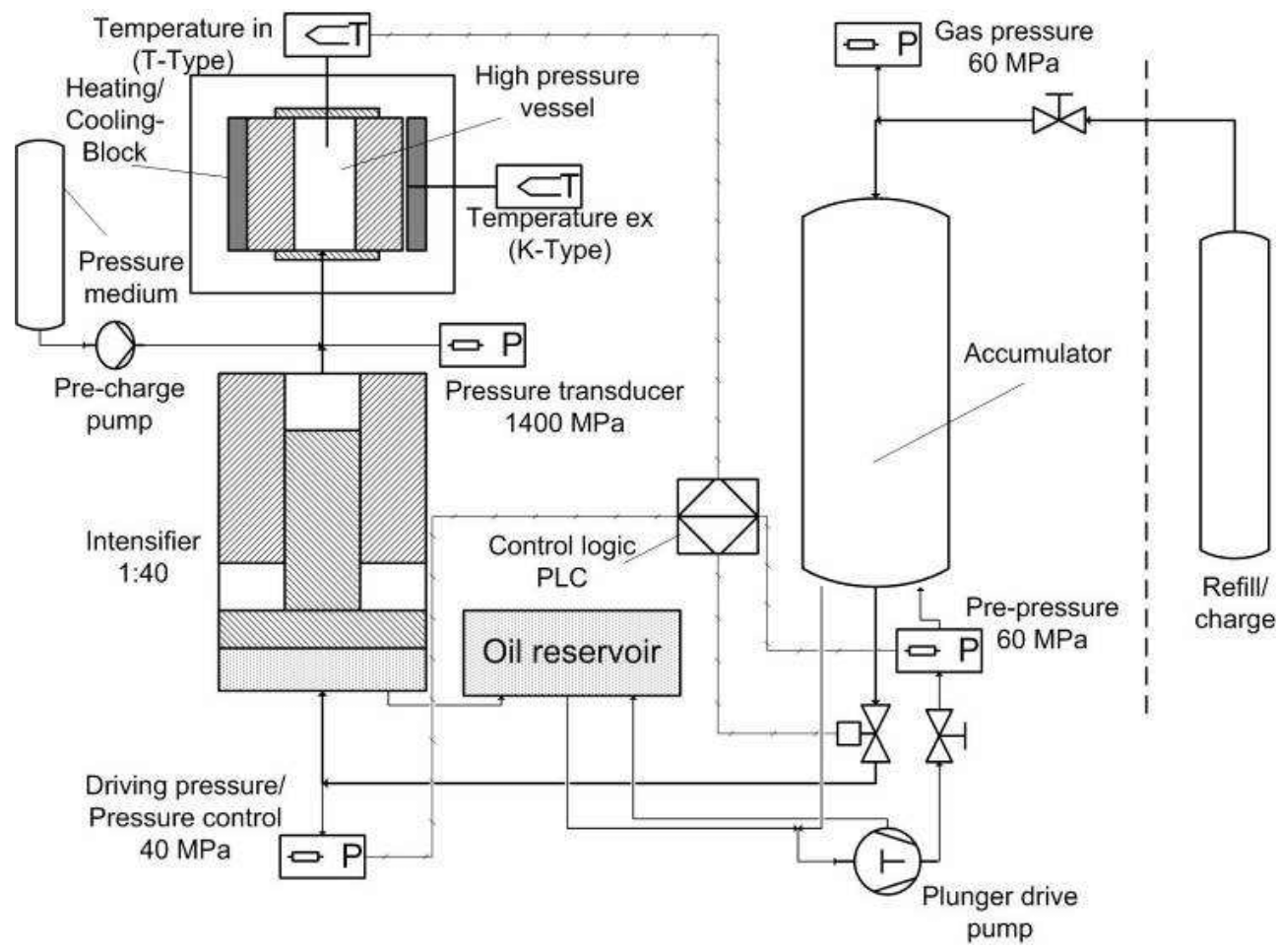

Figure 1. Schematic diagram High pressure vessel with heating cooling system (S-FL-850-9W/FPG5620YHL, Stansted Fluid Power Ltd., Stansted, UK) [13] 
The pressure transmitting medium used was water and was previously adjusted to the desired temperatures with circulating water from a thermo-stating circulator bath (ILB-WCS, STIK Shanghai Co., Ltd.). The temperature of the pressure medium was monitored during processing by a T-type thermocouple fixed inside the vessel. The temperature was maintained by circulation of the temperature controlled fluid through. The compression and decompression took place over a period of $42 \mathrm{~s}$ and $25 \mathrm{~s}$ respectively. The time spent on loading and unloading sample was approximately $1 \mathrm{~min}$.

All samples were heated in a water bath (TW20, JULABO Technology Co. Ltd., Seelbach, Germany) at ambient pressure $(0.1 \mathrm{MPa})$ if not specified.

The pork batters were done with $200 \mathrm{MPa}$ for $10 \mathrm{~min}$ at $10 \pm 2{ }^{\circ} \mathrm{C}$. All samples were heated in a water bath (HH-42, Changzhou Guohua Electrical Appliance Co., Ltd., China) at $80{ }^{\circ} \mathrm{C}$ for $30 \mathrm{~min}$ (internal temperature $72^{\circ} \mathrm{C}$ ), then cooled immediately with running water and stored at $4{ }^{\circ} \mathrm{C}$ for analysis.

\section{Determination of cooking yield} [14]:

The cooking yield of pork batters was calculated according to the following formula

$$
\text { Cooking yield }(\%)=\text { cooked meat batter/raw meat batter } \times 100 \%
$$

Each measurement was replicated 5 times.

\section{Water holding capacity}

The water holding capacity of the samples was measured according to the method of [15]. Sample with casing was weighed (weightsample). After removing the casing from the sample, the surface water of the product was absorbed using filter paper and reweighed

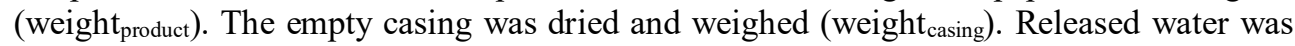
expressed as a percentage of the original weight.

$$
\begin{gathered}
\text { Released } \text { water }(\%)= \\
=\left(\text { weight }_{\text {sample }}-\text { weight }_{\text {product }}-\text { weight }_{\text {casing }}\right) /\left(\text { weight }_{\text {sample }}-\text { weight }_{\text {casing }}\right) \times 100
\end{gathered}
$$

\section{Determination of texture}

Samples were assessed for texture profile analysis (TPA) according to the procedure of [16-18], using a texture analyzer TA-XT plus (Stable Micro Systems Ltd., UK) with an aluminum cylindrical probe $\mathrm{P} / 36 \mathrm{R}$ at ambient temperature $\left(20-25^{\circ} \mathrm{C}\right)$. The indicators of hardness, springiness, cohesiveness and chewiness were determined. Each measurement was replicated 5 times.

Parameters as follow: pre-test speed $2 \mathrm{~mm} / \mathrm{s}$, test speed $2 \mathrm{~mm} / \mathrm{s}$, post-test speed $2 \mathrm{~mm} / \mathrm{s}$, compression ratio $40 \%$, trigger force $5 \mathrm{~g}$, and $5 \mathrm{~s}$ was allowed between the two compression cycles.

The texture profile analysis of cooked pork batters (the cylindrical-shaped with a diameter of $20 \mathrm{~mm}$ and a height of $20 \mathrm{~mm}$ ) were carried out using a texture analyzer (TA-XT plus Texture analyzer, Stable Micro Systems, UK) with an aluminum cylindrical probe P/36R. 


\section{- Food Technology —}

Cylindrical samples (20 mm diameter; $20 \mathrm{~mm}$ height) were axially compressed to $40 \%$ of their original height using a double compression cycle test. The trigger force used for the test was $5 \mathrm{~g}$, with a pretest speed of $2 \mathrm{~mm} / \mathrm{s}$, test speed $2 \mathrm{~mm} / \mathrm{s}$, post-test speed $2 \mathrm{~mm} / \mathrm{s}$. A time of $5 \mathrm{~s}$ was allowed to elapse between the two compression cycles. The data were generated by Exponent software (Exponent stable microsystem, version 5.1.2.0, Stable Microsystems Ltd., UK) provided with the instrument (Figure 2). Attributes of hardness, springiness, cohesiveness, chewiness and resilience were determined. Each measurement was replicated 5 times.

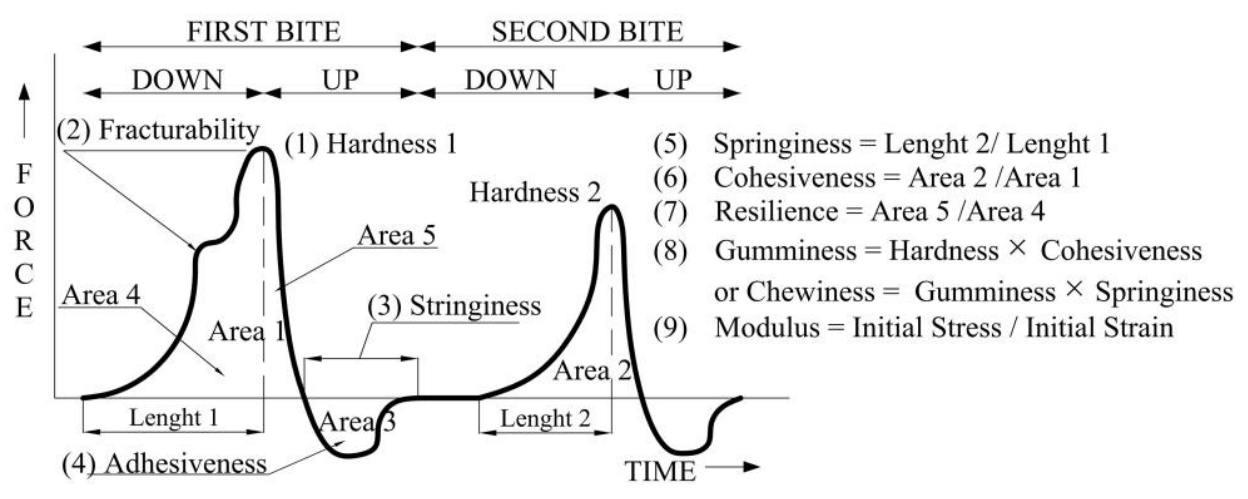

Figure 2. The parameter definition interpretation of qualitative curve analytical method [16]

Hardness. It is the biggest peak of compression for the first time.

Springiness. The quotient or volume ratio of the compressed deformed sample to the predeformed condition after removing the deforming force. Elasticity is expressed by the ratio (Length2/ Length1) of the specimen recovery height (Length 2) measured in the second compression to the first compression deformation (Length 1).

Cohesiveness. The relative resistance of the test sample to the second compression after the first compression deformation is shown in the curve as the ratio of positive work (Area 2/Area 1) of the two compressions. This value represents the total work required to overcome the attraction between the two surfaces when the probe comes into contact with the sample.

Chewiness. It is only used to describe the test sample in solid state, indicating the energy required to chew the solid sample into a stable state when swallowing. The numerical value is expressed by the product of the stickiness and elasticity (hardness x cohesive elasticity).

\section{Low field NMR measurements}

Low field NMR relaxation measurements were carried out according to the method of $[19,32]$. About $2 \mathrm{~g}$ of the cooked pork batter was placed in a $15 \mathrm{~mm}$ glass tube and inserted in the NMR probe of a Niumag Pulsed NMR analyzer (PQ001, Niumag Electric Corporation, Shanghai, China).

Spin-spin relaxation time $\left(\mathrm{T}_{2}\right)$ was measured made a $\tau$-value of $350 \mu$ s by the CarrPurcell-Meiboom-Gill sequence at resonance frequency of $22.6 \mathrm{MHz}, 32{ }^{\circ} \mathrm{C}$. Post processing of T2 data distributed exponential fitting of Carr-Purcell-Meiboom-Gill decay curves were performed by Multi-Exp Inv Analysis software (Niumag Electric Corp., Shanghai, China). Each measurement was replicated 4 times. 


\section{Statistical analysis}

The experiment was four replications. The data was analyzed using the one-way ANOVA program (SPSS v.18.0 for Windows), the difference between means was considered significant at $\mathrm{P}<0.05$.

\section{Results and discussion}

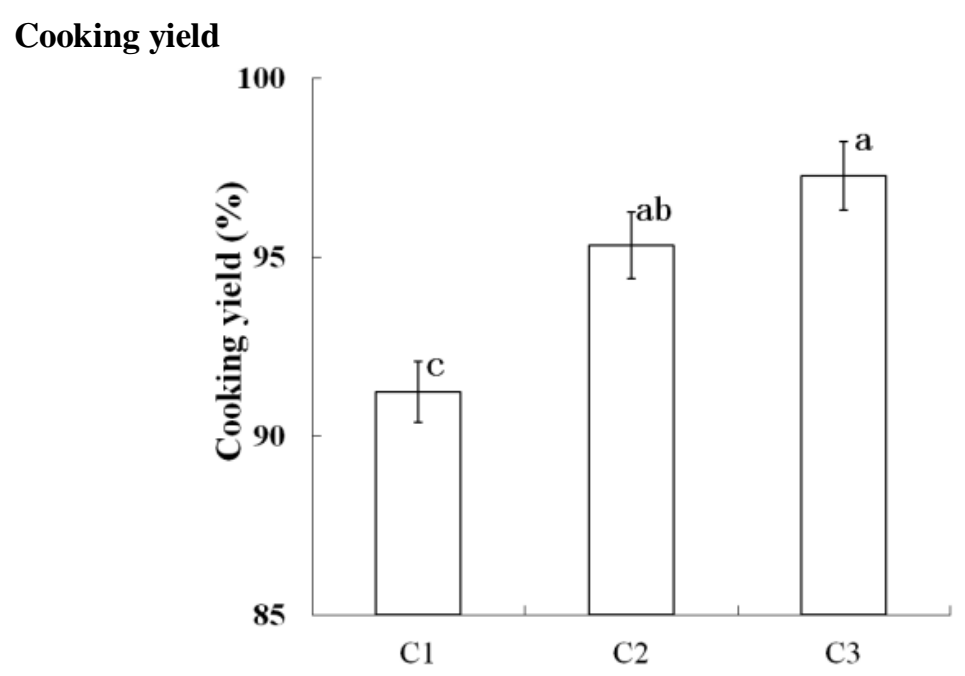

Figure 3. Effect on cooking yield (\%) of pork meat batters by high pressure processing with different soy protein isolate:

$\mathrm{C1}, 0 \mathrm{~g}$ soy protein isolate; $\mathrm{C2}: 10 \mathrm{~g}$ soy protein isolate; $\mathrm{C} 3: 20 \mathrm{~g}$ soy protein isolate.

Each value represents the mean $\pm S D, n=4$.

${ }^{a-c}$ Different parameter superscripts in the figure indicate significant differences $(p<0.05)$

The effect of high pressure with various amount of soy protein isolate on the cooking yield of pork batters was shown in Figure 3. A higher cooking yield of pork batters reflects a better water holding capacity. Compared with the $\mathrm{C} 1$, all the cooking yield of pork batters with various amount of soy protein isolate were increased significantly $(\mathrm{P}<0.05)$, but the cooking yields of $\mathrm{C} 1$ and $\mathrm{C} 2$ were no significantly $(\mathrm{P}<0.05)$ differences. The reason might be that added the $2 \%$ soy protein isolate could hold the water of pork batters very well, so increased the soy protein isolate addition could not improved the cooking yield. The emulsifying activity of $11 \mathrm{~S}$ globulins was much significantly improved at $200 \mathrm{MPa}$, that enhanced the water holding capacity of soy protein isolate [20]. Study [21] authors used of the soy protein isolated, wheat flour (WF), and $\kappa$-carrageenan as binder, showed that the addition of binders improved water-binding properties of pressure or non-pressure-induced restructured pork. The similar result was reported by [22], who used the dried egg white as fat replacement to obtain a low-fat chicken gel by means of high pressure, the water binding properties and hardness were improved, suggested their participation in the network structure coupled to the myofibrillar proteins, and noted that the modifying certain functional characteristics of chicken meat gels with low fat content by means of high pressure and the addition of dried egg white. Thus, the addition of soy protein isolate could improve the cooking yield of pork batters. 


\section{Texture}

Table 1

Texture of cooked pork batters by high pressure processing with different soy protein isolate

\begin{tabular}{|c|c|c|c|c|}
\hline Sample & Hardness (N) & Springiness & Cohesiveness & Chewiness $(\mathrm{N} \mathrm{mm})$ \\
\hline C1 & $47.32 \pm 1.12^{\mathrm{c}}$ & $0.837 \pm 0.008^{\mathrm{b}}$ & $0.641 \pm 0.005^{\mathrm{c}}$ & $27.05 \pm 0.85^{\mathrm{c}}$ \\
\hline C2 & $53.21 \pm 0.98^{\mathrm{a}}$ & $0.863 \pm 0.009^{\mathrm{a}}$ & $0.687 \pm 0.007^{\mathrm{a}}$ & $35.68 \pm 0.89^{\mathrm{a}}$ \\
\hline C3 & $50.42 \pm 1.05^{\mathrm{b}}$ & $0.835 \pm 0.007^{\mathrm{b}}$ & $0.655 \pm 0.008^{\mathrm{b}}$ & $29.67 \pm 0.96^{\mathrm{b}}$ \\
\hline
\end{tabular}

$\mathrm{C} 1,0 \mathrm{~g}$ soy protein isolate; $\mathrm{C} 2: 10 \mathrm{~g}$ soy protein isolate; $\mathrm{C} 3: 20 \mathrm{~g}$ soy protein isolate.

Each value represents the mean $\pm \mathrm{SD}, \mathrm{n}=4$.

${ }^{a-c}$ Different parameter superscripts in the figure indicate significant differences $(p<0.05)$.

The texture of cooked pork batters were affected significant $(\mathrm{P}<0.05)$ by high pressure and soy protein isolate combinations (Table 1). Compared with the $\mathrm{C} 1$, all the hardness, springiness, cohesiveness and chewiness of pork batters with various amount of soy protein isolate were increased significantly $(\mathrm{P}<0.05)$, except the springiness of $\mathrm{C} 3$. Compared with the 4\% (C3), the hardness, springiness, cohesiveness and chewiness of pork cooked batter with $2 \%$ soy protein isolate $(\mathrm{C} 2)$ were significantly increased $(\mathrm{P}<0.05)$. High pressure processing induced texture modifications have been used to affect myofibrillar proteins and their gel-forming properties, raising the possibility of the development of processed comminuted meat products. Over $200 \mathrm{MPa}$ treatment, the protein extractability was decreased significantly in meat batters, and caused protein denaturation and/or aggregation, which limited their functionalities $[23,24]$. Although the soy protein isolate have has a good water and fat holding capacity, excellent gelling and structuring behaviour, some paper have reported that excessive added the soy protein isolate could lower the texture of meat batters [21]. Therefore, the pork cooked batter with $2 \%$ soy protein isolate $(\mathrm{C} 2)$ had the best texture.

\section{Low field NMR}

The effects of relaxation time and peak ration of cooked pork batters by high pressure processing with different soy protein isolate were determined (Table 2). There was three characteristic peaks in the cooked pork batters, which was named as $T_{2 b}, T_{21}$ and $T_{22}$, respectively. $T_{2 b}$ is assigned to water tightly associated to protein and macro-molecular constituents, the relaxation population centered at approximately $0-10 \mathrm{~ms}$ in the cooked pork batters 25[19]. The relaxation population of $T_{21}$ is centered at approximately $10-100 \mathrm{~ms}$, which is a major component and considered to intra-myofibrillar water and water within the protein structure. $\mathrm{T}_{22}$ is corresponds to extra-myofibrillar water and centered at approximately100-400 $\mathrm{ms}[26,27]$ Compared with the $\mathrm{C} 1$, the initial relaxation times of $\mathrm{T}_{2 \mathrm{~b}}$, $\mathrm{T}_{21}$ and $\mathrm{T}_{22}$ were quicker $(\mathrm{p}<0.05)$ in the $\mathrm{C} 2$ and $\mathrm{C} 3$, the result indicated that the cooked pork batters made with various amounts of soy protein isolate were bound tightly, because the changes of fast relaxing protein and slowly relaxing water protons [28,29].

These also were accordance with the changes of texture and cooking yield (Table 1 and Figure 3). The reason was possible that the soy protein isolate had excellent gelling and structuring behaviour, then a better gel structure of cooked pork batters by high pressure processing was formed when added the soy protein isolate [30]. The emulsifying activity of 
$11 \mathrm{~S}$ globulins of soy protein isolate was much significantly improved at $200 \mathrm{MPa}$, through the changes of protein solubility, surface hydrophobicity, free SH content and secondary structure [20,31]. All the peak rations of $\mathrm{T}_{2 b}$ were no significant differences $(\mathrm{p}>0.05), \mathrm{C} 2$ and $\mathrm{C} 3$ had the smallest peak rations of $\mathrm{T}_{22}$, and had the largest peak ration of $\mathrm{T}_{21}$ (Figure 4 ).

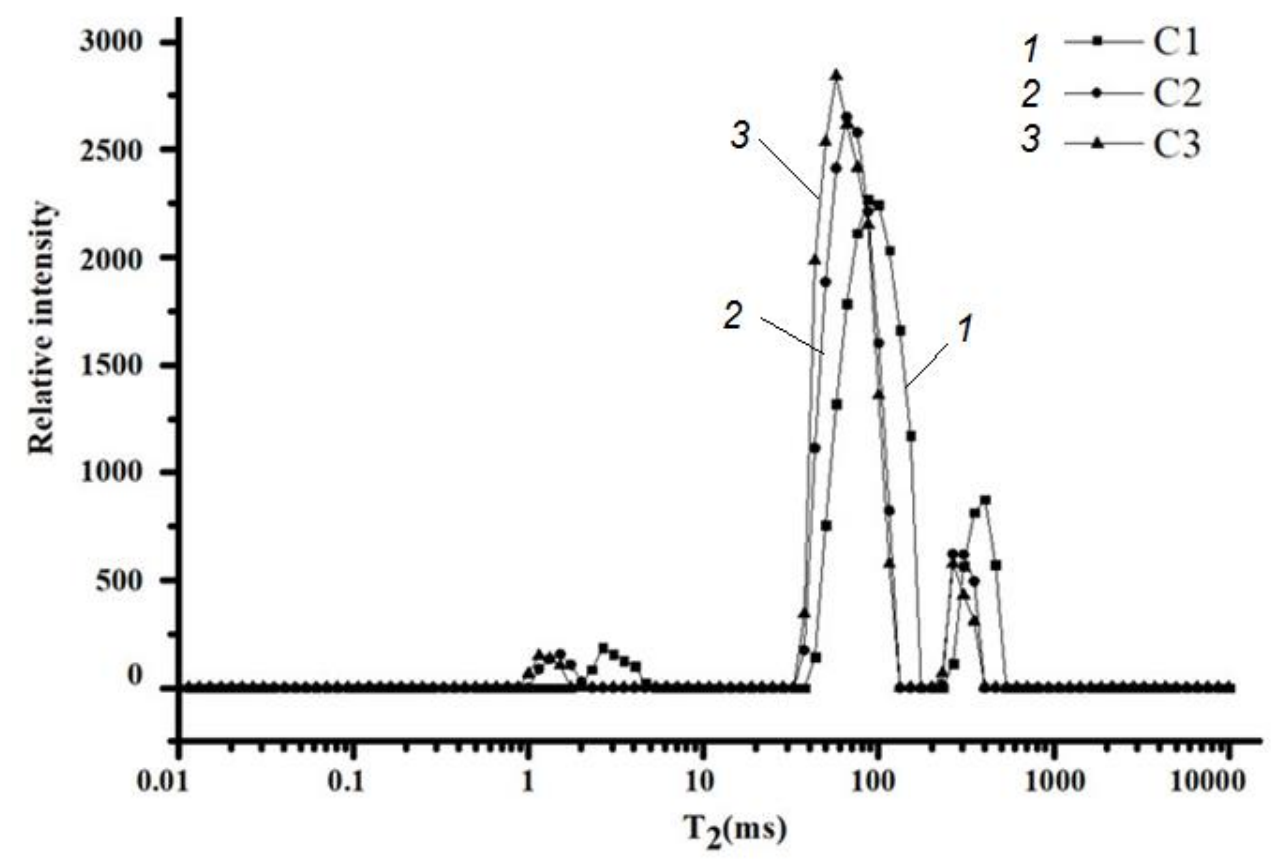

Figure 4. Curves of relaxation time (T2) in cooked pork batters by high pressure processing with 1000 different soy protein isolate

Added the soy protein isolate and high pressure processing combinations could increase the protein content, more meat proteins can become available for gel formation of the meat matrix. These caused the water tightly associated to protein and macromolecular constituents decreased, and improve water holding capacity of cooked meat batters [33]. Therefore, added the soy protein isolate increased the water holding capacity, and improved the texture of cooked meat batters.

Table 2

Relaxation time (ms) and peak ration (\%) of cooked pork batters by high pressure processing with different soy protein isolate

\begin{tabular}{|l|c|c|c|c|c|c|}
\hline \multirow{2}{*}{$\begin{array}{c}\text { Samp- } \\
\text { le }\end{array}$} & \multicolumn{3}{|c|}{ Relaxation time (ms) } & \multicolumn{3}{c|}{ Peak ration (\%) } \\
\cline { 2 - 7 } & $\mathbf{T}_{\mathbf{2 b}}$ & $\mathbf{T}_{\mathbf{2 1}}$ & $\mathbf{T}_{\mathbf{2 2}}$ & $\mathbf{T}_{\mathbf{2 b}}$ & $\mathbf{T}_{\mathbf{2 1}}$ & $\mathbf{T}_{\mathbf{2 2}}$ \\
\hline $\mathrm{C} 1$ & $1.95 \pm 0.13^{\mathrm{a}}$ & $44.23 \pm 1.42^{\mathrm{a}}$ & $265.51 \pm 4.26^{\mathrm{a}}$ & $1.22 \pm 0.15^{\mathrm{a}}$ & $85.66 \pm 2.36^{\mathrm{b}}$ & $13.26 \pm 0.85^{\mathrm{a}}$ \\
\hline $\mathrm{C} 2$ & $1.12 \pm 0.15^{\mathrm{b}}$ & $37.25 \pm 1.59^{\mathrm{b}}$ & $232.87 \pm 4.68^{\mathrm{b}}$ & $0.96 \pm 0.12^{\mathrm{a}}$ & $91.87 \pm 2.45^{\mathrm{a}}$ & $8.31 \pm 0.80^{\mathrm{b}}$ \\
\hline $\mathrm{C} 3$ & $1.06 \pm 0.11^{\mathrm{b}}$ & $36.30 \pm 1.45^{\mathrm{b}}$ & $227.52 \pm 4.31^{\mathrm{b}}$ & $1.03 \pm 0.12^{\mathrm{a}}$ & $93.26 \pm 2.14^{\mathrm{a}}$ & $7.03 \pm 0.86^{\mathrm{b}}$ \\
\hline
\end{tabular}

$\mathrm{C} 1,0 \mathrm{~g}$ soy protein isolate; $\mathrm{C} 2: 10 \mathrm{~g}$ soy protein isolate; $\mathrm{C} 3: 20 \mathrm{~g}$ soy protein isolate.

Each value represents the mean $\pm S D, n=4$. 


\section{Conclusion}

The effect of high pressure and soy protein isolate combinations on the gel properties of pork batters was significant differences $(\mathrm{P}<0.05)$. Compared with the $\mathrm{C} 1, \mathrm{C} 2$ and $\mathrm{C} 3$ had a higher cooking yield and hardness, cohesiveness and chewiness. The result of low field NMR exhibited that the batters with soy protein isolate had less water out the cooked pork batter and free water. Thus, $\mathrm{C} 2$ had the best water holding capacity and texture. Overall, the $2 \%$ soy protein isolate addition could improve the water holding capacity and texture of pork batters treated by high pressure.

\section{Reference}

1. Hygreeva D., \& Pandey M. C. (2016), Novel approaches in improving the quality and safety aspects of processed meat products through high pressure processing technology - A review, Trends in Food Science and Technology, 54(54), pp. 175-185.

2. Chen X., Tume R. K., Xiong Y. L., Xu X., ZhouG., Chen, C., \& Nishiumi, T. (2018), Structural modification of myofibrillar proteins by high-pressure processing for functionally improved, valueadded, and healthy muscle gelled foods, Critical Reviews in Food Science and Nutrition, 58(17), pp. 2981-3003.

3. Rospolski V., Koutchma T., Xue J., Defelice C., \& Balamurugan, S. (2015), Effects of high hydrostatic pressure processing parameters and $\mathrm{NaCl}$ concentration on the physical properties, texture and quality of white chicken meat, Innovative Food Science and Emerging Technologies, 30, pp. 31-42.

4. Chan J. T. Y., Omana D. A., \& Bett, M. (2011), Effect of ultimate pH and freezing on the biochemical properties of proteins in turkey breast meat, Food Chemistry, 127, 109-117.

5. Xu Yan-Teng., Liu Tong-Xun., \& Tang Chuan-He. (2019), Novel pickering high internal phase emulsion gels stabilized solely by soy $\beta$-conglycinin, Food Hydrocolloids, 88, 21-30.

6. Villamonte G., Simonin H., Duranton F., Chéret R., \& de Lamballerie M. (2013), Functionality of pork meat proteins: Impact of sodium chloride and phosphates under high-pressure processing. Innovative Food Science \& Emerging Technologies, 18, 15-23.

7. Yang H., Han M., Wang X., Han Y., WuJ. Xu, X. \& Zhou G. (2015), Effect of high pressure on cooking losses and functional properties of reduced-fat and reduced-salt pork sausage emulsions, Innovative Food Science and Emerging Technologies, 29, 125-133.

8. Wang X., Tang C., Li B., Yang X., Li L., \& Ma C. (2008), Effects of high-pressure treatment on some physicochemical and functional properties of soy protein isolates. Food Hydrocolloids, 22(4), pp. 560-567.

9. Colmenero F. J. (2002), Muscle protein gelation by combined use of high pressure/temperature, Trends in Food Science and Technology, 13(1), pp. 22-30.

10. Zheng H., Han M., Yang H., Tang C., Xu X., \& Zhou G. (2017), Application of high pressure to chicken meat batters during heating modifies physicochemical properties, enabling salt reduction for high-quality products, LWT - Food Science and Technology, 84, pp. 693-700.

11. Berghout J. A. M., Boom R. M., \& Goot A. J. (2015), Understanding the differences in gelling properties between lupin protein isolate and soy protein isolate, Food Hydrocolloids, 43, pp. 465472.

12. Kang Z., Chen F., \& Ma H. (2016), Effect of pre-emulsified soy oil with soy protein isolate in frankfurters: A physical-chemical and Raman spectroscopy study, LWT - Food Science and Technology, pp. 465-471.

13. Operating instructions Mini Foodlab S-FL-850-9-W/FPG5620YHL. 73.

14. Leng Gao, Yang-Ping Huang and Xiao-Chen Gao (2013), Influence of Pre-emulsified Sunflower Oil used for Pork Backfat Replacement in Sika Deer (Cervus Nippon Hortulorum) Frankfurter, Food Sci. Technol. Res., 19(5), pp. 773-780 


\section{— Food Technology}

15. Supavititpatana T., \& Apichartsrangkoon, A. (2007), Combination effects of ultra-high pressure and temperature on the physical and thermal properties of ostrich meat sausage (yor), Meat Science, 76(3), pp. 555-560.

16. Operating instructions texture analyzer TA-XT plus (Stable Micro Systems Ltd., UK), 82.

17. Trespalacios P., \& Pla, R. (2007), Simultaneous application of transglutaminase and high pressure to improve functional properties of chicken meat gels. Food Chemistry, 100(1), pp. 264-272. http://dx.doi. org/10.1016/j.foodchem.2005.09.058.

18. Sanita Sazonova, Ruta Galoburda, Ilze Gramatina, Evita Straumite (2018), High pressure effect on the sensory and physical attributes of pork, Research for rural development, Food science, 1, pp. 227-232.

19. Kang Z. L., Zhu D., Li B., Hanjun M. A., \& Song Z. (2017), Effect of pre-emulsified sesame oil on physical-chemical and rheological properties of pork batters, Food Science and Technology International, 37(4), pp. 620-626.

20. Tang C., \& Ma C. (2009), Effect of high pressure treatment on aggregation and structural properties of soy protein isolate. LWT - Food Science and Technology, 42(2), pp. 606-611.

21. Chun J., Choi M., Min S., \& Hong G. (2014), Effects of binders combined with glucono- $\delta$-lactone on the quality characteristics of pressure-induced cold-set restructured pork, Meat Science, 98(2), pp. 158-163.

22. Trespalacios P., \& Pla R. (2009), Development of low-fat chicken meat and dried egg white gels by high pressure, High Pressure Research, 29(1), pp. 150-161.

23. Oflynn C. C., Cruzromero M. C., Troy D. J., Mullen A. M., \& Kerry J. P. (2014), The application of high-pressure treatment in the reduction of phosphate levels in breakfast sausages, Meat Science, 96(1), pp. 633-639.

24. Sazonova S., Grube M., Shvirksts K., Galoburda R., \& Gramatina I. (2019), FTIR spectroscopy studies of high pressure-induced changes in pork macromolecular structure, Journal of Molecular Structure, DOI: 10.1016/j.molstruc.2019.03.038.

25. Xiong G., Han M., Kang Z., Zhao Y., Xu X., \& Zhu Y. (2016), Evaluation of protein structural changes and water mobility in chicken liver paste batters prepared with plant oil substituting pork back-fat combined with pre-emulsification, Food Chemistry, 196, 388-395.

26. Han M., Wang P., Xu X., \& Zhou G. (2014), Low-field NMR study of heat-induced gelation of pork myofibrillar proteins and its relationship with microstructural characteristics, Food Research International, 62(62), pp. 1175-1182.

27. Rao W., Wang Z., Shen Q., Li G., Song X., \& Zhang D. (2018), LF-NMR to explore water migration and water-protein interaction of lamb meat being air-dried at $35^{\circ} \mathrm{C}$, Drying Technology, 36(3), pp. $1-8$.

28. Pearce K. L., Rosenvold K., Andersen H. J., \& Hopkins D. L. (2011), Water distribution and mobility in meat during the conversion of muscle to meat and ageing and the impacts on fresh meat quality attributes - A review, Meat Science, 89(2), pp. 111-124.

29. Shao J., Deng Y., Song, L., Batur A., JiaN., \& Liu D. (2016), Investigation the effects of protein hydration states on the mobility water and fat in meat batters by LF-NMR technique, LWT - Food Science and Technology, 66, 1-6.

30. HanM. Y., Zhang, Y. J., Fei Y., Xu X. L., \& Zhou G. H. (2009), Effect of microbial trans-glutaminase on NMR relaxometry and microstructure of pork myofibrillar protein gel, European Food Research and Technology, 228(4), pp. 665-670.

31. Molina E., Papadopoulou A., \& Ledward D. A. (2001), Emulsifying properties of high pressure treated soy protein isolates and 7S and 11S globulins, Food Hydrocolloids, 15, 263-269

32. Posudin Yuriy I., Peiris Kamaranga S., Kays, Stanley J. (2015), Non-destructive detection of food adulteration to guarantee human health and safety, Ukrainian Food Journal, 4(2), pp.207-261

33. Ma X., Yi S., Yu Y., Li J., \& Chen J. (2015), Changes in gel properties and water properties of Nemipterus virgatus surimi gel induced by high-pressure processing, LWT - Food Science and Technology, 61(2), pp. 377-384. 